\title{
Developing a Learner-Centered Pharmaceutical Care Course using a Focus Group Approach
}

\author{
Alessandra Rezende Mesquita1', Werlissandra Moreira de Souza ${ }^{2}$, Aline Santana Dosea ${ }^{3}$, Sabrina \\ Cerqueira Santos ${ }^{3}$, Denise Bueno ${ }^{4}$, Angelo Roberto Antoniolli ${ }^{5}$, Wellington Barros da Silva ${ }^{3}$, Divaldo \\ Pereira de Lyra Júnior ${ }^{3, *}$
}

1'Department of Pharmacy, Federal University of Minas Gerais, Belo Horizonte, MG, BRAZIL. ${ }^{2}$ Department of Pharmacy, Federal University of Oeste da Bahia, Barreiras, BA, BRAZIL. ${ }^{3}$ Laboratory of Teaching and Research in Social Pharmacy (LEPFS), Department of Pharmacy, Federal University of Sergipe, São Cristóvão, SE, BRAZIL.

${ }^{4}$ Department of Pharmacy, Federal University of Rio Grande do Sul of College of Pharmacy, Porto Alegre, BRAZIL.

${ }^{5}$ Department of Physiology, University President of Federal University of Sergipe, São Cristovão, BRAZIL.

\begin{abstract}
Background: the aim of this article was to obtain the opinions of a pharmacist teachers group regarding the pharmaceutical care course model most suited to Brazil. Methods: five teachers of pharmaceutical care courses in public Faculty of Pharmacy in Brazil were selected to participate. Participants were asked to provide their perceptions about 3 predetermined questions regarding the content that should be taught in pharmaceutical care course, skills that should be taught in the course, and learning activities that are necessary to develop the knowledge and skills that are taught. Data were subjected to a content analysis. Results: the focus group identified 5 categories related to the students' development of professional identity: competences to pharmaceutical care; challenges to teach; instructional design; learning assessment; and barriers to the application of the teaching method. Conclusion: the report of this focus group shows that new teaching methods should be implemented to ensure effective pharmaceutical care courses.
\end{abstract}

Key words: Dontent analysis, Developing countries, Focus groups, knowledge construction, Teaching / learning strategies.

\section{INTRODUCTION}

In recent years, given increased morbidity and mortality related to drugs, increased rates of chronic diseases, and changing needs of health systems, pharmacists have been encouraged to take a more active role in health care. ${ }^{1-3}$ Consequently, pharmacists have shifted their focus towards preparing medications for patient-centered care and have expanded the range of Pharmaceutical Services. ${ }^{4}$ In 1990, the pharmaceutical care philosophy was defined as "the responsible provision of drug therapy for the purpose of achieving defined outcomes that improve a patient's quality of life". ${ }^{5}$ In this context, the International Pharmaceutical Federation (FIP) has developed programs aimed at developing and implementing pharmaceu- tical care in the daily practice of a clinical pharmacist. $^{2}$

To prepare pharmacy students for this expanding role, colleges and schools of Pharmacy are incorporating components of competency into their curricula. ${ }^{6} \mathrm{Com}-$ petence is defined as a set of observable and measurable behaviors that are reliably causally related to performance rated as good or excellent in particular work environments. ${ }^{7}$ In health care education, competencies are often used as an alternative to outcomes assessments, because they may more accurately reflect a student's or practitioner's ability to perform in a real life setting. ${ }^{8,9}$ The development of professional observable behaviors associated with
Submission Date: 26-10-2016; Revision Date: 03-01-2017; Accepted Date: 15-02-2017

DOI: 10.5530/ijper.53.1.9 Correspondence: Dr. Divaldo Pereira de Lyra Júnior*,

Cidade Universitária "Prof. José Aloísio Campos", Jardim Rosa Elze, São Cristóvão, CEP: 49100-000 BRAZIL.

Phone: +55-79-2105 6319 E-mail: lepfs.ufs@gmail.com

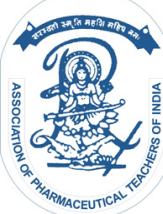

www.ijper.org 
competencies requires the presence of 5 components: knowledge; the ability to put knowledge into practice (the skills); attitudes; motivation; and resources (professional competence, available physical resources, favorable working environment and so forth). ${ }^{7}$

In this way, the clinical training requirements in the pharmaceutical profession have expanded and it has become necessary to develop new competencies related to the practice of clinical subjects, which include solving problems, developing plans of care, communicating effectively, thinking critically, and making decisions. ${ }^{10,11}$ It is important that educators of student pharmacists instill in them a commitment to lifelong learning, which will enable them to maintain and expand their knowledge and skills to better serve patients, the profession, and society as a whole. ${ }^{12}$

According to Salter et al. the fundamental purpose of Pharmacy Education is to provide students with the knowledge and skills to become pharmacists and to enable pharmacists to remain competent in the profession. ${ }^{13}$ Van Der Werf et al. affirm that it is essential to teach students practical pharmacotherapy and clinical issues in a controlled setting to achieve effective learning in pharmaceutical care philosophy and medication therapy management (MTM) practice. ${ }^{14}$ Thereby, research on the teaching of pharmaceutical care has been undertaken in several countries; ${ }^{11,15-17}$ however, qualitative research has been less common.

A systematic review of the literature, conducted by the authors with the purpose of analyzing published studies on the teaching of pharmaceutical care, found no studies of the use of active learning for pharmaceutical care education in Brazil that is the reason for the need of study like this. Thus, this paper describes the results of a focus group conducted to obtain the opinions of a pharmacist teachers group regarding the models of pharmaceutical care and Medication-Therapy Management course that are most suited to Brazil. The objectives of this article was to generate ideas related to the knowledge and skills necessary for Pharmacy students to engage in clinical practice and the learning strategies or teaching methods that foster these competencies.

\section{MATERIAL AND METHODS}

Considering that the goal of pharmaceutical care and MTM courses is to provide graduating students with effective competences in their chosen profession, and it is our responsibility as educators to prepare them to use their knowledge and skills in a professional setting, the goal of this focus group was to understand which skills and knowledge were felt by the teachers to be essential for a successful MTM practice, and the teaching strategies that could be used to effectively teach this material. Previously published focus group methodology was followed. ${ }^{18,19}$ The study was approved by the Human Research Ethics Committee of the Federal University of Sergipe.

\section{Subjects}

Five teachers of pharmaceutical care and MTM courses in public Colleges of Pharmacy in Brazil (in 4 regions of the country) were selected to participate in the focus group. The teachers were selected based on leadership positions, and all were consultants of the Brazilian Pharmaceutical Professional Council. Each invited participant signed a term of consent that described the project goals and notified them that the discussions would be recorded. The teachers were free to withdraw from the focus group at any time, and they were assured that their identity would remain confidential.

\section{Data Collection}

The focus group was conducted in October 2013 in a meeting room in the School of Pharmacy in São Cristovão, Sergipe, Brazil. During the 120-min session, participants were asked to provide their perceptions about how should be a model of pharmaceutical care and MTM course by answering 3 predetermined questions:

What content should be taught in pharmaceutical care and MTM course?

Which skills should be taught in pharmaceutical care and MTM course?

What learning activities are necessary to develop the knowledge and skills taught in pharmaceutical care and MTM course?

The focus group questions were tested with faculty members and with the focus group participants prior to implementation.

A PhD student (ARM) acted as the moderator for the focus group, and another $\mathrm{PhD}$ student (WMS) acted as the assistant moderator. The moderator initiated and maintained the discussion, added questions that followed the direction of the dialogue, and sought clarification as time permitted. The moderator was given the flexibility to redirect questions to allow individual participants to make comments and suggestions that were not directly related to the questions posed. It was also the role of the moderator to ensure that no person was able to dominate the conversation, as well as to ensure that all teachers were given the opportunity to state their opinions. The assistant moderator observed the session, took notes, and monitored the recording device throughout the session. An audio-visual recording of 
the focus group session was taken and later transcribed, but the names of the teachers were not recorded with any of the responses.

\section{Analysis}

Following the focus group discussions, the moderators met for a debriefing to share their perceptions of critical points in the discussions and to gauge their reactions to the focus group process. The responses of the teachers were transcribed and the data were subjected to a content analysis based on the method of Bardin (2006). ${ }^{20}$ To ensure the quality of the data analysis, team members independently read a sub-sample of the transcripts and met regularly to discuss the data and emerging codes, ultimately identifying and agreeing on the main themes. Coding discrepancies were limited and those that occurred were resolved through discussion.

\section{RESULTS}

Analysis of the focus group data identified 5 categories relating to the students' development of professional identity: (1) clinical competencies; (2) challenges to teaching; (3) instructional design; (4) learning assessment; and (5) barriers to the application of the teaching method. The identified codes were organized as described below. To help convey the nature of the categories, a description of each category is provided with a corresponding table showing the subcategories and sense nuclei.

\section{Competencies for Pharmaceutical Care}

This category represents the competencies that, according to the teachers in this focus group, students should achieve in pharmaceutical care and MTM courses. These competencies were divided into 2 subcategories: knowledge and skills. The sense nuclei of the knowledge subcategory contained general content that represents the base of the practice of pharmaceutical care and MTM (eliciting relevant information from the patient, identification of a patient's drug-related needs, establishing goals of therapy and practice management, among others), as well as specific content that should be presented in the course, including morbidity and mortality associated with medications, chronic diseases, the most prevalent acute diseases, mental illness, care at different stages of life, pharmacotherapy, semiology of minor disorders, dispensing medications, drug interactions and analysis of laboratory tests. Table 1 shows also the sense nuclei for the skills subcategory that were addressed during the discussion of pharmaceutical care courses.

\section{Challenges to Teaching}

In this category, the teachers discussed the challenges involved in determining the contents and skills that will be taught as well as choosing a teaching method for the course. They discussed the need for standardization of

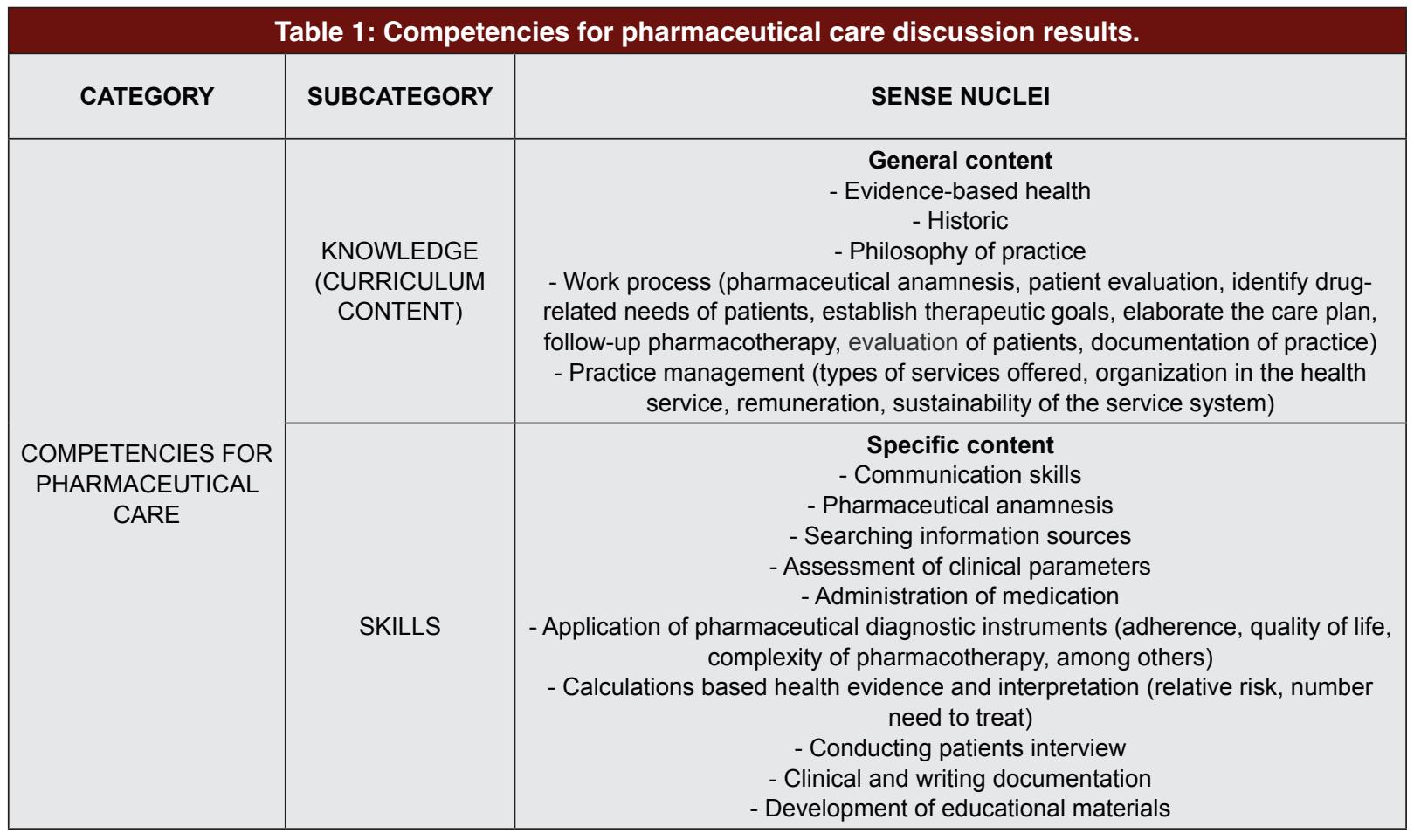


the activities involved in the teaching of pharmacy to undergraduate students and the need to set focus on the profession. Other subcategories raised by the focus group included the adequacy of the planning structure (curricular and physical) and the teaching approach employed (Table 2).

\section{Instructional Design}

This category was divided in two subcategories: characteristics of the teaching methods and the methods themselves. The results of this discussion are shown in Table 3.

\section{Learning Assessment}

This category addresses the need for the learning evaluations to be consistent with the new teaching methods used in the pharmaceutical care and MTM course, and was divided into two subcategories: characteristics of the evaluation methods and the evaluation methods themselves (Table 3).

\section{Barriers to the Application of the Teaching Method}

Table 4 shows the results of the discussion of barriers to the application of the teaching method, including structural barriers and barriers associated with teachers and students.

\section{DISCUSSION}

The method chosen to know the opinion of a group of pharmaceutical teachers about which model to course most appropriate to pharmaceutical care and MTM was focus group. The focus group approach to obtaining qualitative information assumes that individuals with experience in a given area develop opinions, knowledge and insights of substantial potential value to the researcher conducting the study. ${ }^{21}$ Focus groups have high internal validity (the degree to which the researchers are actually observing what they think they are observing) and are less expensive than larger surveys. ${ }^{22,23}$ Thus, they can be used to gather opinions outside of consensus, provide detailed information on perceptions, clarify research findings or design and assess subsequent research. ${ }^{22-25}$

In this focus group, the first point addressed by teachers was the issue of the content of the course. To define the contents of the course, the focus group compared the Pharmacy undergraduate courses with other undergraduate courses in health care, such as nursing and medicine. The main point of discussion was the need to centralize the knowledge of the course in patient care. The statements below illustrate this topic:

"Indeed we will develop clinical knowledge and skills. Pharmaceutical care is the following: we have an instrument that is the medicine, it is not our final goal, it is our instrument. So in our care, the dimension that sets us apart from the doctor, from the nurse, is that we take care of patients in the medication use process."

"When we look at the literature, eg, the books that were developed on pharmaceutical care, they address these three content: the philosophy of the practice, process or model of this practice and the governance or manage-

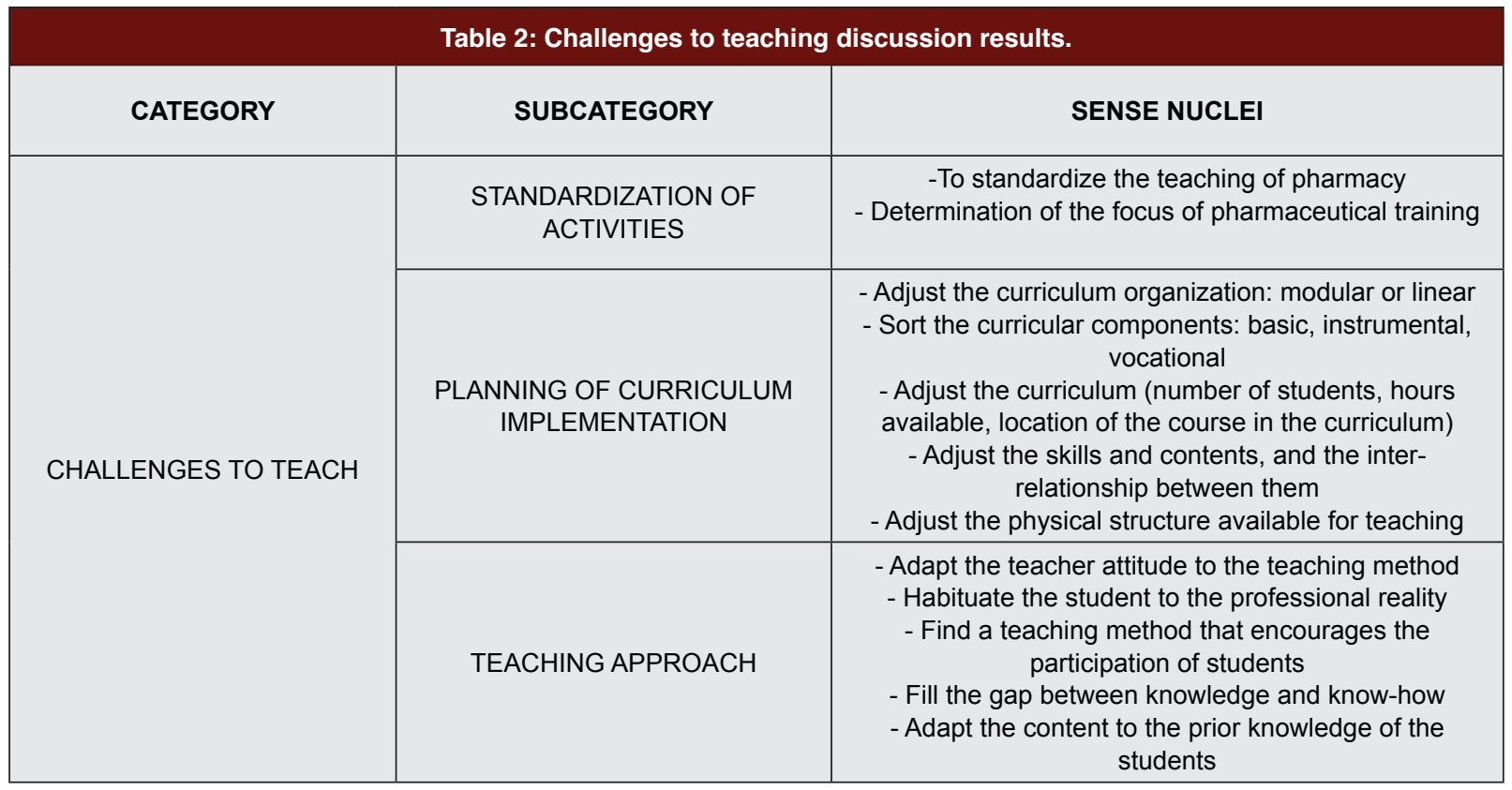




\begin{tabular}{|c|c|c|}
\hline CATEGORY & SUBCATEGORY & SENSE NUCLEI \\
\hline \multirow[b]{2}{*}{ INSTRUCTIONAL DESIGN } & $\begin{array}{l}\text { CHARACTERISTICS OF } \\
\text { TEACHING METHODS }\end{array}$ & $\begin{array}{c}\text { - Allow cross teaching } \\
\text { - Student-centered (active-learning) } \\
\text { - Theoretical and practical approach } \\
\text { - Approach the professional reality } \\
\text { - Patient-centered } \\
\text { - Diversify the teaching approach - learning style } \\
\text { - Learning for adults (andragogy), holographic learning } \\
\text { - Facilitate the process of memorization } \\
\text { - Progression of teaching strategies } \\
\text { - Use technology (Examples: Moodle, Google teacher; film, } \\
\text { video) }\end{array}$ \\
\hline & TEACHING METHODS & $\begin{array}{c}\text { - Case studies } \\
\text { - Problematization } \\
\text { - Interview techniques } \\
\text { - Simulation (simulated patients, role play, OSCE) } \\
\text { - Problem-based learning (PBL) } \\
\text { - Research based learning } \\
\text { - Project-based learning } \\
\text { - Experience based learning or experiential learning } \\
\text { - Service learning } \\
\text { - Clerkship } \\
\text { - Expository dialogical lecture }\end{array}$ \\
\hline \multirow{2}{*}{ EVALUATION OF LEARNING } & $\begin{array}{c}\text { CHARACTERISTICS OF } \\
\text { EVALUATION }\end{array}$ & $\begin{array}{l}\text { - Stimulate the learning process } \\
\text { - Combine methods } \\
\text { - Integrating other disciplines }\end{array}$ \\
\hline & METHODS OF EVALUATION & $\begin{array}{c}\text { - Peer evaluation } \\
- \text { Simulation } \\
\text { - Practical evaluation (e.g. competitions, games) }\end{array}$ \\
\hline
\end{tabular}

\begin{tabular}{|c|c|c|}
\hline \multicolumn{2}{|c|}{ Table 4: Barriers to teaching discussion results. } \\
\hline \multirow{2}{*}{ CATEGORY } & SUBCATEGORY & SENSE NUCLEI \\
\hline \multirow{2}{*}{$\begin{array}{c}\text { BARRIERS TO } \\
\text { TEACHING }\end{array}$} & $\begin{array}{c}\text { STRUCTURAL AND OF } \\
\text { CURRICULUM }\end{array}$ & $\begin{array}{c}\text { - Lack of practical classes } \\
\text { - Lack of physical structure (laboratories simulation) } \\
\text { - Insufficient credit hours } \\
\text { - Current curriculum guidelines }\end{array}$ \\
& $\begin{array}{c}\text { - High number of students per teacher } \\
\text { - Lack of monitors }\end{array}$ \\
\cline { 2 - 3 } & ASSOCIATED TO TEACHERS AND \\
STUDENTS & - Incompatible teacher profile \\
& & - Difficulty of teachers in providing feedback \\
\hline
\end{tabular}

ment of the practice. As well as in the nursing process course."

A study conducted by Kassam and Volume-Smith ${ }^{26}$ confirmed these notions, and showed that pharmaceutical care required that the student have the knowledge to assume responsibility for the management of drugrelated problems and to evaluate a patient's drug therapy outcomes over time. Thus, each patient should receive counseling and a monitoring plan, and students should document the care they have provided. In addition to this general content, the focus group also addressed specific knowledge, including knowledge of specific diseases, care at different life stages and pharmacotherapy. Regarding the skills that should be taught in pharmaceutical care course, the following statements exemplify the opinion in the focus group:

"If we think in terms of clinical skills, we have really practical activities as patient exams, particularly vital signs ... know how to use the database, collect information and interpret information, to apply information, anamnesis as an important part of clinical documentation." 
"So ... are always those skills, I have to know how to communicate, I have to know perform a clinical interview, I have to know to document, I must know to register, I must know how to write a communication, a report, an opinion to another professional. I got to know elaborate some kind of educational material to the patient and I must to have skills also management of my practice."

Similar findings were reported by Cherenson $\mathrm{et} \mathrm{al} .{ }^{27}$ in which the 10 skills most important for students and practitioners in a clinical practice were evaluated. All pharmacists and pharmacy students were in agreement that patient counseling, profile review for detecting and resolving drug-related problems, communication with health care professionals, drug information skills, documentation of interventions and monitoring of drug therapy were important. The clinical skills identified by participants in this study were also in line with those identified by Kassam and Volume-Smith, ${ }^{26}$ who developed and implemented a community clerkship program. It is worth mentioning that the importance of the connection between skills and knowledge was discussed in this focus group. Skills are part of the psychomotor domain and combine with knowledge, i.e. the cognitive domain, to achieve student learning. ${ }^{28}$ According to the literature, the curriculum should not be focused only on content, knowledge, but rather put the student at the center of the process and plan the results according to the knowledge, skills, behaviors, attitudes and values that should be achieved. ${ }^{29,30}$ Once outcomes are set forth, teaching and learning strategies are then developed to support the achievements of the students.

During the discussion of the skills to be taught, some participants highlighted characteristics that are challenges to the teaching of pharmaceutical care. One example is the lack of uniformity in the Pharmacy curriculum in Brazil and the lack of standardization of the egress profile. For example:

"...I think we're at a moment where we need to decide whether or not we want to teach pharmaceutical care to undergraduates. In my view, in one discipline is not possible to do it. We must understand the true mission of our profession, and not produce pharmacists who have learned everything, but don't know how to do anything."

Since 1990, other studies have demonstrated that pharmacists are the health care professionals most suited to provide pharmaceutical care and that skill development related to pharmaceutical care should be an important component of the Pharmacy undergraduate program. ${ }^{31-33}$ In other countries this concern is also perceived. As an example, in Canada, the Council for
Accreditation of Pharmacy Programs has determined that the students are trained with competencies to practice pharmaceutical care. ${ }^{34}$

Another feature that should be noted is the teaching approach. The group's opinion about how the teacher can determine the most appropriate choice of teaching method is illustrated below:

"And in the end, is what sets the creativity of the teacher, not worth it to use a transformer method if the teacher is authoritarian, if his profile did not combine with that method, because sometimes it is preferable to use an expositive method, understand?"

According to Abate et al. educators and faculty in the health science disciplines often do not receive specific education or training concerning instructional approaches, learning theories, or how to best facilitate student learning. Furthermore, these authors mentioned the lack of time as a barrier for educators to learn the educational theories and advantages/disadvantages of various instructional methods. ${ }^{29}$ In contrast, Stewart et al. conducted a survey to identify the use of activelearning strategies by teachers and found that $87 \%$ of the 1,179 respondents reported the use of at least one active-learning strategy in their classroom activities, with problem-based learning reported most commonly $(71 \%) .{ }^{35}$

Regarding teaching methods used in the pharmaceutical care and MTM course, the group emphasized that, independent of the method chosen, some characteristics are important for the method to effectively achieve student learning. One of these features is the approach to the patient, which can be illustrated by the following statement:

"I think that regardless of the method chosen, how you will transmit this content has to approach of the patient, whether, for example, working with clinical case or simulate the care to the patient ... to be not only lecture, ie only provide content. I think this is totally flawed. How to fail in the teaching of pharmaceutical care? Is your approach not be patient-centered."

Others studies show that an emphasis must be placed on the processes utilized by pharmacists to communicate with individual patients in order to identify and solve their drug-related problems, which will allow students to learn how to directly apply knowledge and skills. ${ }^{26,36}$ Despite this finding, Zaremski et al. ${ }^{37}$ and Kassam et al. ${ }^{16}$ found that a large proportion of students in the United States experienced insufficient opportunities to practice the patient-centered activities, tasks and processes that are essential to pharmaceutical care. 
The need to use teaching methods that are learner-centered, i.e., active learning methodologies was also clear. For example:

“. . . The (WHO) World Health Organization itself says that the major problems existing in healthcare today is the gap between knowing and doing. So, to minimize this gap, I think we need transformative educational practices. Thus, you use what you have available to generate content and facilitate skills development in the most participatory way possible ..."

"How to teach patient-centered practice in a way that is not focused on the student? It is impractical to teach in a way that is not student-centered. So the practice model that we want to teach must necessarily be centered on the learner, on the student."

Traditional teaching methods, such as lectures, are commonly used in higher education and may be particularly beneficial for topics requiring lower cognitive levels of learning for which students are primarily recalling information or describing/explaining concepts. ${ }^{29}$ However, if achievement of outcomes requires higher levels of cognitive learning (e.g., application, analysis, synthesis), lectures alone will likely be inadequate to meet course outcomes, because lectures place students in a passive, rather than active, role. This occurs because the learning depends on the relationship between numerous concepts to form the so-called semantic networks. Process that is facilitated by experimentation. ${ }^{29}$ Thus, when the learners themselves are the center of the learning process (i.e., student-centered learning), they structure, organize, and use new information gained through interactions with their environment that allow for construction of their own knowledge..$^{29,38}$

In this sense, Van Amburgh et al. ${ }^{39}$ points out that preparing pharmacy students for practice in the modern healthcare system requires that we rethink pharmacy teaching methodology and go beyond the traditional lecture-based delivery of factual material to incorporate methods that allow for effective application and problem solving in the classroom. In this focus group, several methods were cited that could be used in pharmaceutical care course. A systematic review carried by authors, with the purpose to analyze the published studies about the teaching of pharmaceutical care found 25 studies, using different teaching methods, including problembased learning, case studies and simulations.

Active learning has numerous advantages, including effectively bridging the gap between licensure and actual patient experience, engaging students more deeply in the process of learning by encouraging critical thinking, and fostering the development of self-directed learning. These methods benefit students and instructors by allowing to student the practice and development of competences, and to instructors the opportunity to provide immediate feedback of students' learning. ${ }^{29,39}$ Because of these advantages, the 2007 Accreditation Council for Pharmacy Education (ACPE) Standards and Guidelines addresses the need for active-learning techniques in every phase of pharmacy student education and in continuing professional development for pharmacists. ${ }^{40}$

In addition to the recommendation to use active-learning methods, the literature recommends that educators take into consideration the learning style preferences of undergraduate pharmacy students when developing curricula and evaluating teaching approaches, especially when planning, implementing and evaluating education initiatives in order to create an effective, contemporary learning environment for their students. ${ }^{41}$ This point was addressed in the focus group as follows:

"I think anyone who wants to develop a student-centered teaching approach must adopt strategies that consider two important factors: learning is a process, and learning is a highly individual experience. Each student has a way of learning, and this fact must be taken into consideration. There is the influence of the collective, there is the socialization process of learning, but the concrete experience of learning is individual. Therefore any strategy has to consider that people learn in different ways, with different mechanisms and different strategies."

Related to the use of active teaching methods is the importance of technology. As active-learning techniques have been encouraged in pharmacy education, an increase in the use of technology has often followed. As noted by Oblinger, ${ }^{42}$ the expectations of students raised on the Internet and interactive games may not be achieved in colleges and universities with traditional infrastructure and learning strategies, as lectures. A variety of technological tools are being used in pharmacy education, including computer-assisted instruction, web-based course development/management software, virtual patients and audio/video recordings. ${ }^{43,44}$ Several studies evaluating specific technologies have found positive results, primarily derived from user preferences. ${ }^{45-47}$ However, others studies about the incorporation of technologies and their impact in learning should be undertaken. ${ }^{43}$

The focus group also addressed the need for an evaluation method that is consistent with the new teaching methods. From a cognitive psychology perspective, testing involves retrieving information from memory or retrieval. The literature show that the key mediator of information retention it is the act of retrieving 
information stored in memory (e.g., testing/self-testing) and not the encoding of information in the brain (e.g., rereading notes). ${ }^{48,49}$ Thus, methods that promote rapid initial learning is not equivalent to information long-term retention. However techniques that involve slower, more effortful learning can enhance long-term retention. ${ }^{12}$ Abate et al. affirm that testing is important because the development of student learning outcomes is the foundation to building curricula. Learning outcomes must guide the instructional design of the course and they should be derived from the educational mission of the institution. ${ }^{29}$ Thus, in Pharmacy the learning objectives should be suitable to clinical practice.

Barriers to the implementation of new teaching methods in pharmaceutical care and MTM courses were discussed by the focus group. Examples include the lack of resources and the number of students per teacher. According to the literature, tasks such as identifying the most appropriate assessment to use for each type of outcome and interpreting results can be daunting, because most pharmacy faculty lacks background and education/training in these areas. Thus, to development of an adequate program assessment plan are needed resources. ${ }^{29}$ Kassam and Volume-Smith ${ }^{26}$ described the limited number of preceptors who were comfortable with the practice of MTM and the lack of patient care services in community pharmacies that incorporated essential activities of pharmaceutical care as barriers to learning.

There are some limitations to our study. We conducted only one focus group, which may introduce some uncertainty in reaching theoretical saturation. In addition, the results from this focus group, as qualitative research, cannot be extrapolated to other situations.

\section{CONCLUSION}

This study identified skills and knowledge that are perceived by teachers as important in clinical pharmacy practice, for example: identification of a patient's drugrelated needs, establishing goals of therapy, communication skills, among others. The suggestions presented in this focus group show the need to implement different teaching methods, such as problem-based learning, case studies and simulations, to enable learning for students in pharmaceutical care and MTM courses. The next step is to implement and evaluate the new program and determine whether desired learning objectives are being met.

\section{ACKNOWLEDGMENT}

We acknowledge the teachers of pharmaceutical care by contributions.

\section{CONFLICTS OF INTEREST}

The author declare no conflicts of interest.

\section{FUNDING}

The authors disclosed receipt of the following financial support for the research, authorship, and or publication of this article: Brazilian National Council for Technological and Scientific Development (Capes; Coordination of Superior Level Staff Improvement).

\section{REFERENCES}

1. Fincham JE. Global Public Health and the Academy. Am J Pharm Educ. 2006;70. https://doi.org/10.5688/aj700114.

2. International Pharmaceutical Federation (FIP). The international forum for quality assurance of pharmacy education: a global framework for quality assurance of pharmacy education. http://www.fip.org/files/fip/ PharmacyEducation/Global\%20Framework\%20Final\%20Draft.pdf ; 2008 Accessed June 15, 2012.

3. Hämeen-Anttila K, Saano S, Vainio K. Professional Competencies Learned Through Working on a Medication Education Project. Am J Pharm Educ. 2010;74(6):110. https://doi.org/10.5688/aj7406110. PMid: 21045952 PMCid:PMC2933019.

4. World Health Organization (WHO). Developing pharmacy practice: a focus on patient care. Geneva: WHO. 2006;87.

5. Hepler CD, Strand LM. Opportunities and responsibilities in pharmaceutical care. Am J Hosp Pharm. 1990;47(3):533-43. PMid:2316538.

6. Schellhase EM, Miller ML, Ogallo W, Pastakia SD. An Elective Pharmaceutical Care Course to Prepare Students for an Advanced Pharmacy Practice Experience in Kenya. Am J Pharm Educ. 2013;77(3):60. https://doi. org/10.5688/ajpe77360; PMid:23610478 PMCid:PMC3631735.

7. Span. Modelo de gestión por competencias del Sistema Sanitario Público de Andalucía. Sevilla, SP: Consejería de Salud. 2006;96.

8. Maitreemit P, Pongcharoensuk P, Kapol N, Armstrong EP. Pharmacist perceptions of new competency standards. Pharm Pract. 2008;6(3):113-20. https://doi.org/10.4321/s1886-36552008000300001.

9. McConnell EA. Competence vs. competency. Nurs Manag. 2001;32(5):14 https://doi.org/10.1097/00006247-200105000-00007.

10. Fisher RC. The potential for problem-based learning in pharmacy education: A clinical therapeutics course in diabetes. Am J Pharm Educ. 1994;58(2):1839.

11. Petkova V, Dimitrova ZL. Pharmaceutical practice, pharmaceutical care and pharmacy education in Bulgaria. Pharm Educ. 2003;3(3):205-7. https://doi.or g/10.1080/1560221031000151291.

12. Hagemeier NE, Mason HL. Student pharmacists' perceptions of testing and study strategies. Am J Pharm Educ. 2011;75(2):35. https://doi.org/10.5688/ ajpe75235.

13. Salter SM, Karia A, Sanfilippo FM, Clifford RM. Effectiveness of e-learning in pharmacy education. Am J Pharm Educ. 2014;78(4):83. https://doi. org/10.5688/ajpe78483; PMid:24850945 PMCid:PMC4028592.

14. Van DWJJ, Dekens-Konter J, Brouwers JRBJ. A New Model for Teaching Pharmaceutical Care Services Management. Pharm Educ. 2004;4(3):1-5. https://doi.org/10.1080/15602210400013368.

15. Chiang YC, Lee CN, Lin YM, Yen YH, Chen HY. Impact of a continuing education program on pharmacists' knowledge and attitudes toward 
asthma patient care. Med Princ Pract. 2010;19(4):305-11. https://doi. org/10.1159/000312718; PMid:20516708.

16. Kassam R, Poole G, Collins JB. Development of an instrument to assess the impact of an enhanced experiential model on pharmacy students' learning opportunities, skills and attitudes: A retrospective comparative experimentalist study. BMC Medic Educ. 2008;8(1):17. https://doi.org/10.1186/1472-6920-817; PMid: 18397530 PMCid:PMC2375875.

17. Strohfeldt K, Grant DT. Instructional design and assessment: A model for selfdirected problem-based learning for renal therapeutics. Am J Pharm Edu. 2010;74(9):1-7. https://doi.org/10.5688/aj7409173.

18. Flick U. An introduction to qualitative research. $5{ }^{\text {a }}$ Ed. Berlin: Sage Publications Inc. 2014.

19. Patton MQ. Qualitative evaluation and Research Methods. $3^{\mathrm{a}}$ Ed. London: Sage Publications Inc. 2002.

20. Bardin L. Análise de conteúdo. 70 Ed. Lisboa: PT; 2011

21. Reutzel TJ, DeFalco PG, Hogan M, Kazerooni PV. Evaluation of a pharmaceutical care education series for chain pharmacists using the focus group method. J Am Pharm Assoc. 1999;39(2):226-34. https://doi. org/10.1016/S1086-5802(16)30494-6.

22. Suda KJ, Bell GC, Franks AS. Faculty and Student Perceptions of Effective Study Strategies and Materials. Am J Pharm Educ. 2011;75(10):201. https:// doi.org/10.5688/ajpe7510201; PMid:22345720 PMCid:PMC3279044.

23. Krueger RA. Developing questions for focus groups. Focus Group Kit 3. Thousand Oaks, CA: Sage Publications Inc. 1998;1-18. https://doi. org/10.4135/9781483328126.

24. Krueger RA. Planning focus groups. Focus Group Kit 2. Thousand Oaks, Calif: Sage Publications Inc; 1998.

25. Krueger RA. Analyzing and reporting focus group results. Focus Group Kit 6. Thousand Oaks, CA: Sage Publications Inc. 1998. https://doi. org/10.4135/9781483328157.

26. Kassam R, Volume-Smith Cl. Focus group methodology to develop a community pharmaceutical care clerkship program. Am J Pharm Educ. 2003;67(3):88. https://doi.org/10.5688/aj670388.

27. Cherenson RS, Bilger R, Mohr S, Wuller C. Design of a Pharmaceutical Care Laboratory: A Survey of Practitioners. Am J Pharm Edu. 2005;69(1):3. https:// doi.org/10.5688/aj690103.

28. Bloom B, Englehart M, Furst E, Hill W, Krathwohl D. Taxonomy of educational objectives: The classification of educational goals. Handbook I: Cognitive domain. New York, Toronto: Longmans, Green; 1956.

29. Abate MA, Stamatakis MK, Haggett RR. Excellence in Curriculum Development and Assessment. Am J Pharm Edu. 2003;67(3):89. https://doi. org/10.5688/aj670389.

30. Kern DE, Thomas PA, Howard DM, Bass EB. Curriculum Development for Medical Education: A Six Step Approach. Baltimore, MD: The Johns Hopkins University Press. 1998.

31. Foppe VMJW, Fernandez-Llimos F. What is 'pharmaceutical care' in 2013. Int J Clin Pharm. 2013;35:1-2. https://doi.org/10.4321/s188636552013000100001.

32. DeOliveira DR. Por uma formação crítico-humanista do profissional da atenção farmacêutica: Um ensaio reflexivo. Boletín Red Sudam Aten Farm. 2011;5:1.

33. Silva WB. A emergência da atenção farmacêutica: um olhar epistemológico e contribuições para o seu ensino. [doctoral thesis]. Universidade Federal de Santa Catarina. Florianópolis: Santa Catarina, Brazil. 2009.
34. Association of Faculties of Pharmacy of Canada. Educational Outcomes for First Professional Degree Programs in Pharmacy (Entry-to-Practice Pharmacy Programs) in Canada. http://www.afpc.info/sites/default/files/ AFPC\%20Educational\%200utcomes.pdf.

35. Stewart DW, Brown SD, Clavier CW, Wyatt J. Active-Learning Processes Used in US Pharmacy Education. Am J Pharm Educ. 2011;75(4):68. https:// doi.org/10.5688/ajpe75468; PMid:21769144.

36. Wislande N. Large group problem-based learning: A revision from traditional to pharmaceutical care-based therapeutics. Am J Pharm Edu. 1994;58(1):6473.

37. Zaremski DG, Boyer G, Vlasses PH. A survey of advanced community pharmacy practice experiences in the final year of the PharmD curriculum at the US colleges and schools of pharmacy. Am J Pharm Educ. 2005;69(1):1018.

38. DiPiro JT. Why Do We Still Lecture?. Am J Pharm Educ. 2009;73(8):137. https://doi.org/10.5688/aj7308137; PMid:20221329 PMCid:PMC2828296.

39. Van AJA, Devlin JW, Kirwin JL, Qualters DM. A Tool for Measuring Active Learning in the Classroom. Am J Pharm Educ. 2007;71(5):85. https://doi. org/10.5688/aj710585; PMid:17998982 PMCid:PMC2064883.

40. Accreditation Council for Pharmacy Education (ACPE). Accreditation standards and guidelines for the professional program in pharmacy leading to the Doctor of Pharmacy degree. Accreditation Council for Pharmacy Education. Effective http://www.acpeaccredit.org/pdf/ACPE_Revised_ PharmD_Standards_Adopted_Jan152006.pdf. 2007.

41. Williams $B$, Brown $T$, Etherington J. Learning style preferences of undergraduate pharmacy students. Curr Pharm Teach Learn. 2013;5(2):1109. https://doi.org/10.1016/j.cptl.2012.09.003.

42. Oblinger D. Boomers, gen-Xers and millenials: understanding the new students. Educause Rev. 2003;38(4):37-47.

43. Jabbur-Lopes MO, Mesquita AR, Silva LMA, Almeida Neto A, Lyra JDP. Virtual Patients in Pharmacy Education. Am J Pharm Educ. 2012;76(5):92. https://doi.org/10.5688/ajpe76592; PMid:22761533 PMCid:PMC3386043.

44. Monaghan MS, Cain JJ, Malone PM, Chapman TA, Walters RW, Thompson DC, Riedl ST. Educational technology use among us colleges and schools of pharmacy. Am J Pharm Educ. 2011;75(5):87. https://doi.org/10.5688/ ajpe75587; PMid:21829261 PMCid:PMC3142974.

45. Cook D, Levinson A, Garside S, Dupras D, Erwin P, Montori V. Internet-based learning in the health professions: Ameta-analysis. JAMA. 2008;300(10):118196. https://doi.org/10.1001/jama.300.10.1181; PMid:18780847.

46. Davis J, Crabb S, Rogers E, Zamora J, Khan K. Computer-based teaching is as good as face to face lecture-based teaching of evidence based medicine: A randomized controlled trial. Med Teach. 2008;30(3):302-7. https://doi. org/10.1080/01421590701784349; PMid:18484458.

47. Seybert A, Kobulinsky L, McKaveney T. Human patient simulation in a pharmacotherapy course. Am J Pharm Educ. 2008;72(2):37. https://doi. org/10.5688/aj720237; PMid:18483603 PMCid:PMC2384212

48. Karpicke $\mathrm{J}$, Roediger $\mathrm{H}$. Repeated retrieval during learning is the key to long-term retention. J Memory and Language. 2007;57(2):151-62. https://doi. org/10.1016/j.jml.2006.09.004.

49. Kolers P, Roediger H. Procedures of mind. J Verbal Learning and Verbal Behavior. 1984;23:425-49. https://doi.org/10.1016/S0022-5371(84)90282-2.

Cite this article: Mesquita AR, Souza WM, Dosea AS, Santos SC, Bueno D, Antoniolli AR, et al. Developing A Learner-Centered Pharmaceutical Care Course Using A Focus Group Approach. Indian J of Pharmaceutical Education and Research. 2019;53(1):61-9. 